\title{
PREDICTION OF LAND USE CHANGE AND ECOSYSTEM SERVICES VALUE: A CASE STUDY IN NANPING, CHINA
}

\author{
FAN, X. C. ${ }^{1}-$ ZHAO, L. L. ${ }^{2}-$ HONG, T. ${ }^{1}-$ LIN, H. ${ }^{1}-$ HONG, W. ${ }^{1 *}$ \\ ${ }^{I}$ Forestry College, Fujian Agriculture and Forestry University, 350002 Fuzhou, China \\ (phone:+86-157-2743-5965) \\ ${ }^{2}$ College of Urban and Rural Construction, Shaoyang College, 422000 Shaoyang, China \\ (phone:+86-157-7406-0460) \\ *Corresponding author \\ e-mail:15727435965@126.com \\ (Received $5^{\text {th }}$ Jun 2018; accepted $17^{\text {th }}$ Jul 2018)
}

\begin{abstract}
Changes in land use affect the structure, processes, and functions of ecosystems, and thus influence the ability of ecosystems to serve human beings. The prediction of land use and ecosystem services value can provide reference for the rational planning of land resources and relevant policymaking. Based on the CA-Markov model and the service value per unit area of terrestrial ecosystems in China, the area of land use types and ecosystem services value were predicted for 2030 and the corresponding countermeasures and suggestions were put forward. The study found that from 2015-2030, the area of forest land had the largest increase, while the area of land for construction had the largest decrease. The spatial distribution of land use in 2030 was predicted to be almost the same as that in 2015 . The slight increase in the value of ecosystem services in 2030 was mainly due to improvement in the service capacity of waste treatment and gas regulation. The contribution rate of the service value of forest land to the total ecosystem services value was predicted to gradually decrease from 2015-2030.
\end{abstract}

Keywords: landsat, LUCC, urbanization, Nanping, CA-Markov

\section{Introduction}

Land use involves the long-term and cyclical management activities undertaken on land through use of biological resources and technology in accordance with the natural characteristics of the land and the purposes of economy and society (Fu et al., 2013, 2015; Lawler et al., 2014; Song et al., 2015). Ecosystem services refer to the environmental conditions and utilities formed by ecosystems necessary for the survival and development of human beings (Tolessa et al., 2016; Gaglio et al., 2017; Inkoom et al., 2017). Land use change affects the composition, function, and processes of ecosystems by altering the type of land cover, thereby affecting the availability of ecosystem services and human well-being (DeFries et al., 2004; Koellner et al., 2013). Prediction of land use change is a topic of interest in current research on land use change (Liu et al., 2009). However, there is less research in this area at present. Research on the prediction of land use change and ecosystem services value is helpful for governments to realize the ecological planning of land with comprehensive consideration of the national economy and social development (Inkoom and Frank and Fürst, 2017), to understand the supply capacity and demand of land in order to develop programs for land use planning according to the optimization of the ecological environment and sustainable development (Simmons et al., 2008; Cetin, 2016), and to carry out eco-friendly land use in order to fully utilize the ecological functions of land to ensure ecological security and to promote sustainable land use (Cetin, 2015; Cetin et al., 2018). 
Land use change assessment examines the land's utility and its limitations. According to the intended use of land, the assessment can be divided into the suitability of land for agriculture and cities. The assessment allows us to clarify whether the regional land is suitable for production in various industries, such as agriculture, fruit, forestry, aquaculture, and urban construction, and can also examine the quantity, quality, and distribution of land resources with unreasonable use. It provides scientific basis for the adjustment of regional land use structure and planning. Therefore, land use change assessment is an important method for studying land use change and developing land use policy (Veldkamp and Verburg, 2004).

The land use change model is a powerful tool for land use assessment, and it can help decision-making authorities to formulate land use policies (Veldkamp and Verburg, 2004; Verburg et al., 2004). Land use models can be divided into three categories according to different combinations. The first is a quantitative prediction model, such as the Markov model (Yang et al., 2007; Subedi et al., 2013). This model is based on probability theory and stochastic processes, which can be used to predict land use changes in future years or decades using the initial state of various types of land use and mathematical algorithms, such as the transfer matrix. It is more commonly used in the prediction of land use change because the conditions for using the model are simple; only the area and transfer matrix of land use categories are needed to predict land use changes in future decades. However, the model is not perfect because it cannot reflect the spatial location information, but instead simulates the changes in area of various types of land (Kim and Lee, 2007).

The second type of model is a spatial prediction model, such as a cellular automaton model. This type of model adds spatial information. The cellular automaton model, or CA model, was invented by von Neumann in 1950 (Zhao et al., 2011). This model is based on cells with discrete properties that are scattered in a grid with a set of rules and are changed according to changing rules. Cells with various properties form a complex system through simple interactions. However, there are deficiencies in these cells. The state of a cell in the next moment depends on the state of itself and its neighboring cells. However, the state of the cell should also be related to socio-economic factors, such as population, policies, and transportation ( $\mathrm{Li}$ et al., 2010). In addition, the simulation accuracy of the CA model is affected by the subjectivity of land use conversion rules.

In addition to the above-mentioned models, there is a third type of model called the CA-Markov model, which is the coupling of the first two models. This coupled model has the advantages of the first two models in that it has both spatial information and improved accuracy of land use simulation (Ramezani and Jafari, 2014). Therefore, we used the CA-Markov model to predict land use changes and ecosystem services value in this study.

The Western Taiwan Straits Economic Zone was established in 2010. Fujian Province is at the core of the zone, and it also includes areas in Zhejiang Province and Jiangxi Province. It aims to cooperate with Taiwan to establish a new pole of economic growth in the southeast of China, thus driving economic growth in China. Nanping City, the study area, is located in the central position of the Economic Zone because it is situated at the border of Fujian Province, Jiangxi Province, and Zhejiang Province. Therefore, it has an important significance in predicting the change in land use and ecosystem services value in Nanping. In addition, Nanping City is at the headstream of the Minjiang River, which is the drinking water source for Fujian Province. Therefore, research on the prediction of land use change and ecosystem services value in Nanping 
can provide useful information for ecological security, using land resources rationally, alleviating the contradiction between humans and land, and promoting social harmony and sustainable development.

In this study, we aimed to determine the future change in land use and ecosystem services value in Nanping City from 2015 to 2030 based on the CA-Markov model and the equivalent value per unit area of ecosystem services created by Costanza (1997) and Xie et al. (2006, 2010). This research not only can reveal the future change in land use and ecosystem services value in Nanping, but also can provide a reference for scientific and effective land use planning and for research on ecosystem services value in other provinces and regions.

\section{Materials and methods}

\section{Study area}

Nanping City was chosen as the study area in this research. It is located in the southeast part of China across the sea from Taiwan (Fig. 1).

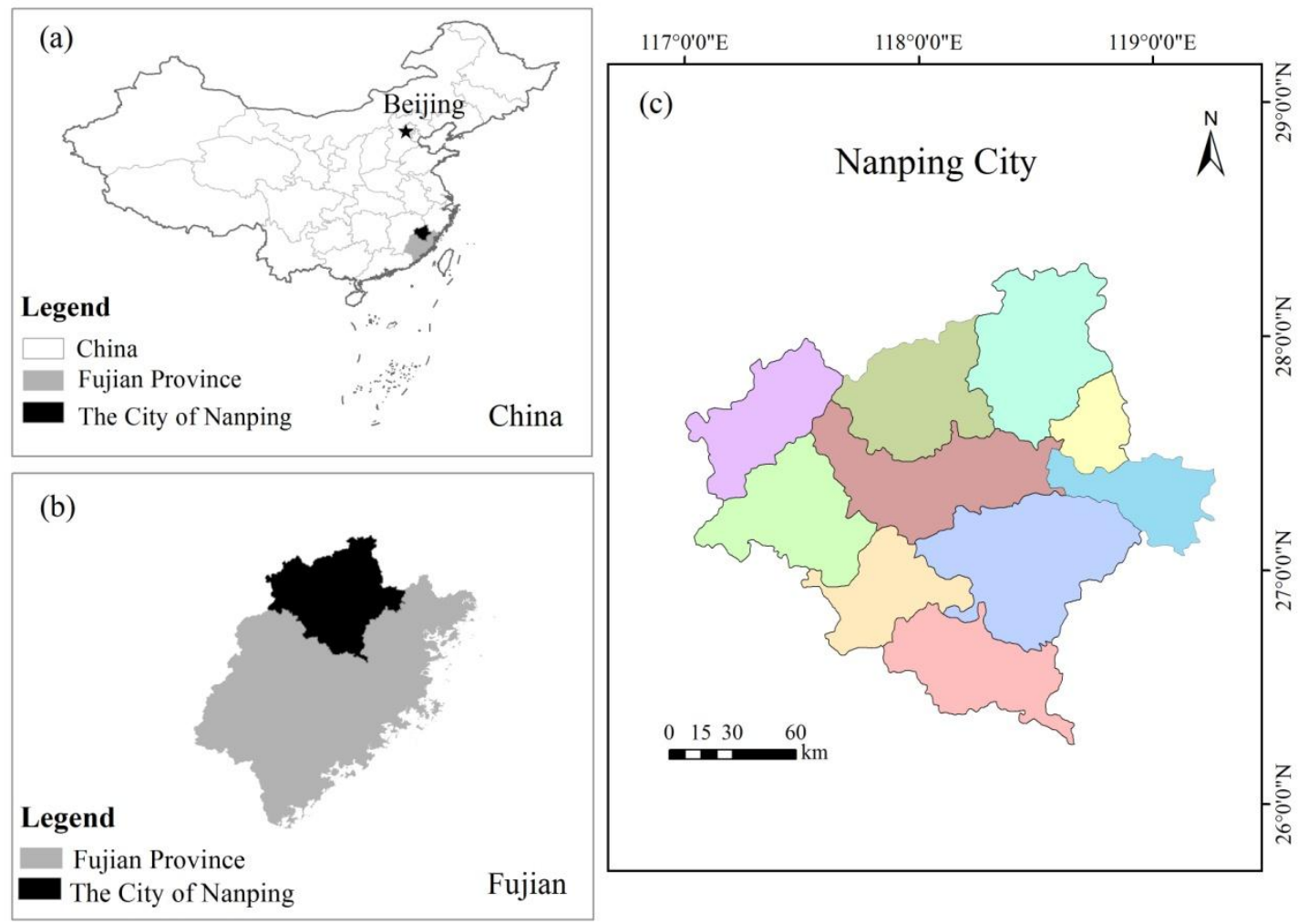

Figure 1. Map of study area

The area has a subtropical humid monsoon climate with an annual average temperature of $17-19^{\circ} \mathrm{C}$, an average winter temperature of $6-9{ }^{\circ} \mathrm{C}$, an average summer temperature of 28-29 ${ }^{\circ} \mathrm{C}$, and an average annual rainfall of 1684-1780 mm. Nanping City has a history of over 4,000 years and is one of the cradles of culture in Fujian Province. Nanping City is the largest city in the province with an area of $26,300 \mathrm{~km}^{2}$, accounting for about one-fifth of the total area of the province. The area of cultivated land and 
forest land in Nanping accounts for approximately one-quarter of that in the province. The area of bamboo forest land accounts for approximately one-tenth of that in China. By the end of 2015, the forest coverage rate was $74.75 \%$, the total household registration population was 3.2 million, and GDP was 20.933 billion USD. Nanping is also the food production base of Fujian Province; its grain output ranks first among that of other cities in the province. Nanping has one of the best ecological environments compared to other areas at the same latitude. Wuyishan, which is under the jurisdiction of Nanping, is one of the four World Natural and Cultural Heritage Sites in China.

\section{Data source}

\section{Acquisition and processing of remote sensing data}

We downloaded remote sensing images, including Landsat 5 (2005 and 2010) and Landsat 7 (2015) images, from the Chinese Geospatial Data Cloud (Xu et al., 2016). The images from Landsat 7 were processed using strip processing. The images with cloud coverage of less than $10 \%$ were selected. Seven scenes fully covered the total study area, so twenty-one scenes were downloaded for the research. Then, color synthesis, mosaic, clipping, and object-oriented classification were conducted using ENVI 5.2 to process these images.

In this study, bands 5, 4, and 3 (RGB) were used for color synthesis. According to the needs of the study and the geographical features of Nanping City, we divided the land use types into 6 categories, including forest land, grassland, cultivated land, construction land, water area, and unused land. After the object-oriented classification was conducted, post-classification maps for three periods were created (Fig. 2). Finally, the areas of all land use types for three periods were extracted using ENVI (Table 1).
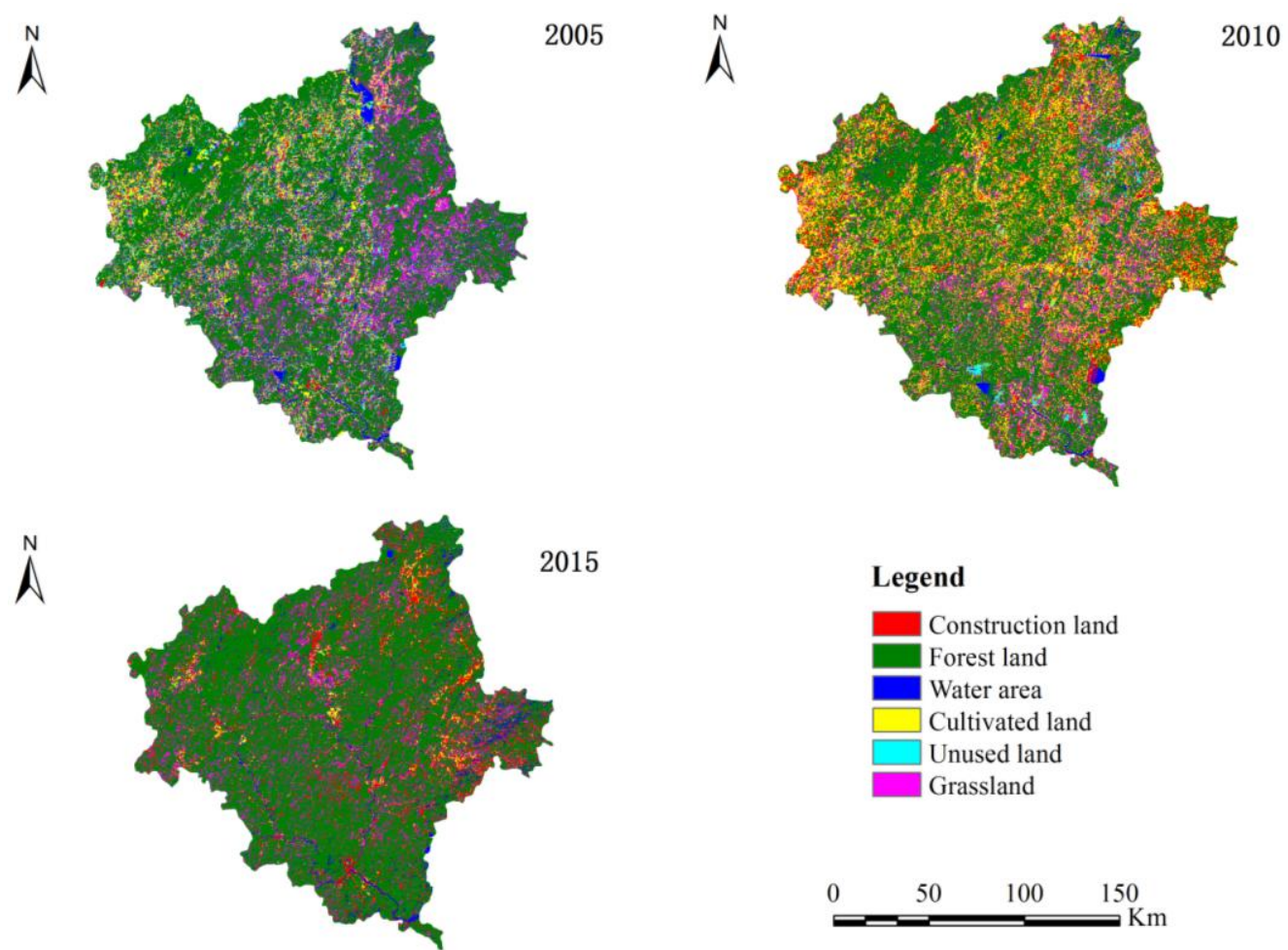

Figure 2. The distribution of land use types in three periods in Nanping 
Table 1. Area of different land use types in three periods $\left(\mathrm{km}^{2}\right)$

\begin{tabular}{c|c|c|c}
\hline Land use types & $\mathbf{2 0 0 5}$ & $\mathbf{2 0 1 0}$ & $\mathbf{2 0 1 5}$ \\
\hline Construction land & 498.94 & 1350.44 & 1101.63 \\
Forest land & 19495.21 & 19258.94 & 21380.69 \\
Water area & 712.06 & 645.76 & 624.84 \\
Cultivated land & 2124.34 & 2452.60 & 1106.44 \\
Unused land & 1076.98 & 770.43 & 410.36 \\
Grassland & 2362.45 & 1796.45 & 1644.75 \\
\hline
\end{tabular}

\section{Preparation for creation of a suitability atlas}

In this study, the CA-Markov module in IDRISI 17.0 was used to predict land use change in Nanping City. A gradient vector map and vector maps of the water system buffer and administrative center buffer were needed before using the CA-Markov model.

\section{Acquisition of the gradient map}

Chinese land use planning is a project of the development, utilization, governance and protection of land in a specific area, time and space according to the requirements of Chinese sustainable development as well as local natural and economic conditions (Zhang and Feng, 2017). According to the grading standards adopted in Chinese Land Use Planning, the slope of land use in Nanping City was divided into five grades (Table 2). The gradient map was then obtained using digital elevation model (DEM) and ArcGIS 10.1 software (Fig. 3). It can be seen from Table 2 that the area with a gradient $>6^{\circ}$ accounted for $84.73 \%$ of the total study area, while the area with a gradient of $0-6^{\circ}$ only accounted for $15.27 \%$ of the total area. This also confirms that mountains are the major landform in Nanping.

Table 2. Gradient classification and area in Nanping City

\begin{tabular}{c|c|c|c}
\hline Grades & Gradient $\left({ }^{\circ}\right)$ & Area $\left(\mathbf{k m}^{\mathbf{2}}\right)$ & Proportion $(\%)$ \\
\hline 1 & $0-2$ & 1009.52 & 3.85 \\
2 & $2-6$ & 2995.24 & 11.42 \\
3 & $6-15$ & 9978.90 & 38.05 \\
4 & $15-25$ & 8290.77 & 31.60 \\
5 & $>25$ & 3954.76 & 15.08 \\
\hline
\end{tabular}

Acquisition of the buffer maps of the water system and administrative centers

The buffer maps of the water system and administrative centers (Fig. $4 b$ and $d$ ) were obtained by setting up four buffer zones at intervals of $1 \mathrm{~km}$, which was the influence area of the water system and administrative centers, by means of distribution maps of the water system, the county government, and ArcGIS 10.1 (Fig. $4 a$ and c). 


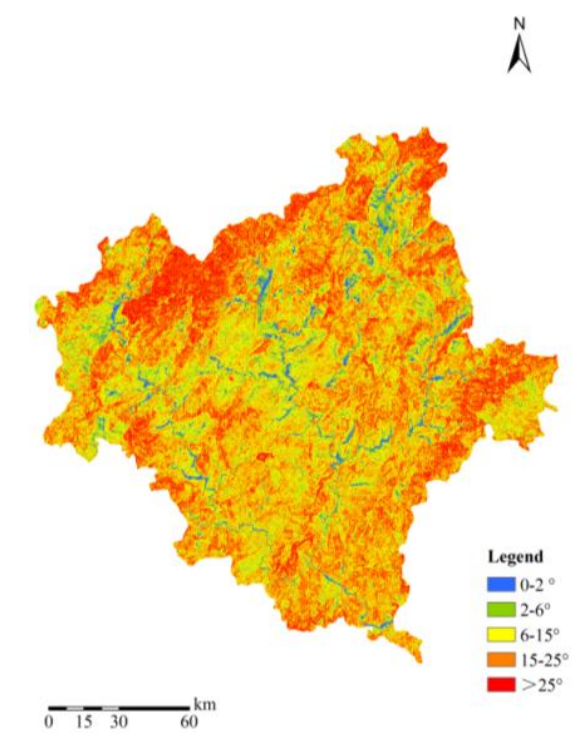

Figure 3. Gradient map of Nanping City

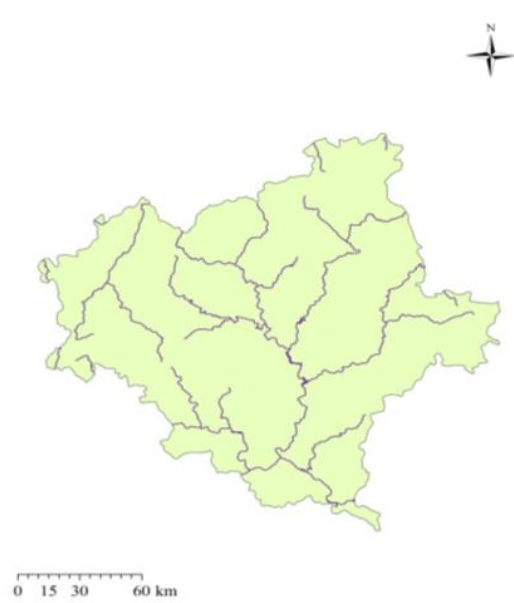

$\mathbf{a}$

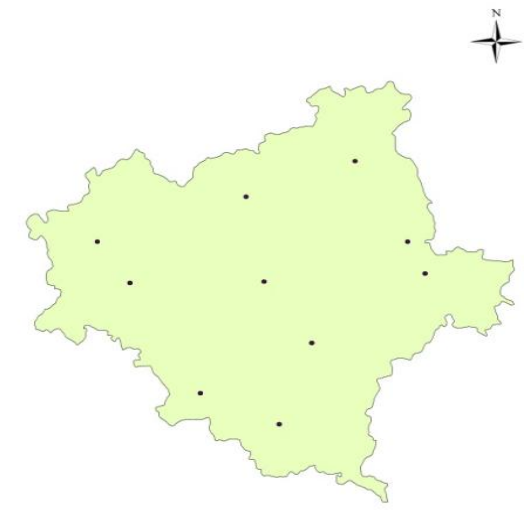

$\begin{array}{llllll}0 & 15 & 30 & 60 & \mathrm{~km}\end{array}$

c

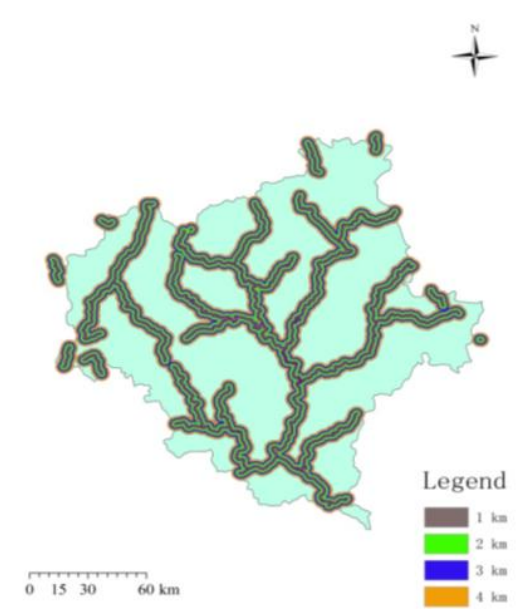

b

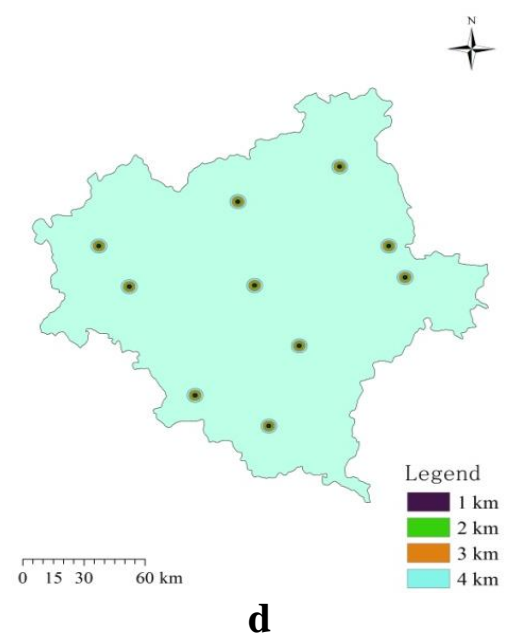

Figure 4. a Distribution of the water system in Nanping City. $\boldsymbol{b}$ The buffer of the water system in Nanping City. $\boldsymbol{c}$ Distribution of the county government administrative centers in Nanping City. $\boldsymbol{d}$ The buffer of the county government administrative centers in Nanping City 


\section{Study methods}

\section{CA-Markov model}

The CA model was proposed by Stanislaw Ulam in the 1940s. It has been widely used in geography, ecology, information science, military science, social science, and other fields since being improved by a number of scholars.

The CA model formula is as follows (Eq. 1):

$$
A=\left(G, U, E, f_{x}\right)
$$

where, $G$ represents the cell grid; $U$ refers to the cell neighborhood; $E$ is the initial state of the cell; $f_{x}$ represents the transformation rules of cell $x$; and $A$ is the cellular automaton model.

Each cell is in different states at different times, and the states change according to the rules. Cellular automaton can be seen as a model of cellular assembly with rules. It can be used to study land use change because it can change over time and space, which is similar to the process of land use change, and the structure and composition of the cells in cellular automata are similar to those of raster data.

The Markov model can also be used to predict land use change using a transition probability matrix. Equation 2 describes the transition process from land use type $E_{t}$ to another land use type $E_{j} . P_{0}$ is the probability of land use type $E_{t}$ being transformed to another land use type $E_{j}$.

$$
P\left(E_{t} \rightarrow E_{j}\right)=P\left(\frac{E_{t}}{E_{j}}\right)=P_{0}
$$

Equation 3 is the state transition probability matrix. $P_{i j}$ represents the state transition probability from land use type $E_{i}$ to another land use type $E_{j}$.

$$
P_{i j}=\left[\begin{array}{cccc}
P_{11} & P_{12} & \mathrm{~K} & P_{1 n} \\
P_{21} & P_{22} & \mathrm{~K} & P_{2 n} \\
\mathrm{M} & \mathrm{M} & \mathrm{M} & \mathrm{M} \\
P_{n 1} & P_{n 2} & \Lambda & P_{n n}
\end{array}\right]
$$

Before using the Markov model, we must assume that the change in each land use type is only related to the state in the present moment, and not related to the state in any previous moment. At the same time, the probability of transition from one type of land use to any other type of land use is needed (Eqs. 4 and 5).

$$
\left\{\begin{array}{c}
0 \leq P_{i j} \leq 1(i, j=1,2, \Lambda, n) \\
\sum_{j=1}^{n} P_{i j}=1(i=1,2, \Lambda, n)
\end{array}\right.
$$




$$
\pi_{j}(k)=\sum_{i=1}^{n} \pi_{i}(k-1) P_{i j}(j=1,2, \Lambda, n)
$$

where $\pi_{j}(k)$ represents the probability that the land use type transitions into the final land use type after the passing of $k$ time from the initial state. $P_{i j}$ is the transition probability from one state of land use to another.

We can achieve the value of $P_{i j}$ from Equation 6:

$$
P_{i j}=\frac{f_{i j}}{\sum_{j=1}^{n} f_{i j}}
$$

where $f_{i j}$ represents the time of transition from state $i$ to state $j$ in one step.

$$
S^{(k)}=S^{(0)} \cdot \pi_{j}^{(k)}
$$

where $S^{(k)}$ is the state of land use at $k$ moment. $S^{(0)}$ is the initial state of land use and $\pi_{j}^{(k)}$ represents the transition probability matrix after $K$ steps. From Equation 7 we can obtain the state of land use at any time by means of the initial state of land use and the transition probability matrix after $K$ steps.

Both the CA model and Markov model are discrete mathematical models in terms of time and state. They are widely used in the fields of geography and ecology. However, they both have drawbacks. The Markov model relies mainly on the transfer matrix of each type of land use to make a prediction. It does not take into account the fact that the driving force of land use change is constantly changing. In addition, the Markov model can provide data on how land use will change, but cannot predict the spatial distribution of land use change. Therefore, the accuracy of predicting land use change using the Markov model is lacking. The CA model can simulate the dynamic spatiotemporal changes of land use in the future. However, the prediction accuracy of the CA model depends on the conversion rules of land use, which are subjective. Additionally, the state of the cells in the CA model are not only affected by spatial location, but are also affected by many other aspects, such as nature, economy, and society. To summarize, the CA-Markov model combines the Markov model and the CA model, and takes into account the impact of the drivers of land use change, thereby more accurately predicting land use change in the study area.

\section{Operation of IDRISI}

In this study, the CA-Markov module in IDRISI 17.0 was used to predict the land use change in Nanping City. The grid maps of land use post-classification, Markov transfer probability matrix, and multi-criteria evaluation module (MCE) suitability atlas were prepared before using the model to predict trends in land use change.

Grid maps of land use post-classification

The vector maps of land use post-classification described in 2.2.1 were transformed into grid maps using the conversion tool of ArcGIS 10.1. 
Markov transfer probability matrix

The matrices of the Markov transfer probability from 2005-2010 and from 20102015 were obtained using IDRISI: GIS Analysis-Change/Time Series-Markov (Tables 3 and 4).

Table 3. The transfer probability matrix of land use from 2005-2010 (\%)

\begin{tabular}{c|c|c|c|c|c|c}
\hline 2010 & $\begin{array}{c}\text { Construction } \\
\text { land }\end{array}$ & Forest land & Water area & $\begin{array}{c}\text { Cultivated } \\
\text { land }\end{array}$ & Unused land & Grassland \\
\hline Construction land & 27.04 & 8.86 & 14.73 & 14.51 & 16.07 & 9.48 \\
Forest land & 27.27 & 65.62 & 33.71 & 31.90 & 29.17 & 28.59 \\
Water area & 4.76 & 2.84 & 17.39 & 4.02 & 3.05 & 2.65 \\
Cultivated land & 33.27 & 13.66 & 25.94 & 35.90 & 36.79 & 32.92 \\
Unused land & 0.85 & 0.85 & 0.71 & 1.38 & 1.59 & 1.06 \\
Grassland & 6.81 & 8.17 & 7.52 & 12.29 & 13.33 & 25.30 \\
\hline
\end{tabular}

Table 4. The transfer probability matrix of land use from 2010 to 2015 (\%)

\begin{tabular}{c|c|c|c|c|c|c}
\hline 2015 2010 & $\begin{array}{c}\text { Construction } \\
\text { land }\end{array}$ & Forest land & Water area & $\begin{array}{c}\text { Cultivated } \\
\text { land }\end{array}$ & Unused land & Grassland \\
\hline Construction land & 18.05 & 1.20 & 13.53 & 14.04 & 9.60 & 9.67 \\
Forest land & 64.39 & 87.93 & 51.51 & 56.66 & 58.87 & 60.02 \\
Water area & 3.75 & 1.47 & 26.67 & 2.91 & 4.37 & 1.92 \\
Cultivated land & 3.58 & 4.52 & 2.91 & 2.39 & 10.44 & 3.33 \\
Unused land & 0.20 & 1.80 & 0.17 & 0.39 & 1.98 & 0.28 \\
Grassland & 10.03 & 3.08 & 5.21 & 18.52 & 14.74 & 24.78 \\
\hline
\end{tabular}

Creation of a suitability atlas

A suitability atlas is a set of images containing rules. Using the atlas can better simulate the influence of factors on land use change. The creation of the atlas is a key and difficult component in predicting land use change. We used the MCE module in IDRISI to create the suitability atlas. In the MCE module, we set up the images according to Boolean rules, which were that 1 indicated suitability and 0 indicated unsuitability, and conversion rules. These conversion rules were as follows:

(1)The conversion rules of cultivated land

a) The area with a slope $>25^{\circ}$ was chosen as an unsuitable area for cultivated land.

b) The zones within $2 \mathrm{~km}$ of administrative centers were set as inappropriate areas for cultivated land.

(2)The conversion rules of construction land

a) The conversion of construction land to any other type of land use was forbidden.

b) The conversion of an area with a slope $>15^{\circ}$ to construction land was forbidden.

(3)The conversion rules of forest land, grassland, and water area 
The restrictions of forest land, grassland, and water area were simpler compared to other types of land because of their functions of environmental protection. Hence, their rules were as follows:

a) The conversion of forest land and grassland to cultivated land was prohibited.

b) The conversion of water area within $1 \mathrm{~km}$ of a water system to construction land was forbidden.

(4)The conversion rules of unused land

The conversion of unused land to other types of land use was prohibited, and unused land could only be allocated to areas with a larger gradient.

Suitability images for each land use type were created by combining each image, obtained using the rules above, using Boolean intersection in the MCE module. We then created the suitability atlas using the Collection Editor tool. Finally, the future change in land use in Nanping was predicted using the CA-Markov module in IDRISI.

\section{Accuracy of the prediction of land use change}

In order to ensure the feasibility of the CA-Markov model in predicting land use change, we tested the accuracy of the model. There were two ways to test the accuracy: the quantitative accuracy test, which tested the accuracy of the structure and quantity of land use types; and the spatial accuracy test.

The quantitative accuracy test

The equation of this method is as follows (Eq. 8):

$$
a=\frac{x_{i b}-x_{i a}}{x_{i b}} \times 100
$$

where $a$ is the error precision and $i$ indicates a specific land use type. $x_{i b}$ and $x_{i a}$ represent the values of the predicted and actual areas, respectively. When $a>0$, it indicates that the predicted value is greater than the actual value.

The spatial accuracy test

$$
y=\frac{\left|\left(x_{i b}-x_{i c}\right)+\left(x_{i a}-x_{i c}\right)\right|}{x_{i a}} \times 100
$$

where $y$ represents the spatial error of the land use prediction and $i$ indicates a specific land use type; $x_{i a}$ and $x_{i b}$ represent the number of cells in the reference image and the predicted image, respectively; and $x_{i c}$ represents the cell number of the overlapping parts of $x_{i a}$ and $x_{i b}$.

Value per unit area of ecosystem services

According to the research results of Costanza et al. (Costanza, 1997) and Xie et al. (Xie et al., 2006, 2010) combined with the actual situation in China, a table of equivalent value per unit area of terrestrial ecosystem services in China was created, 
which provides a reference for the calculation of ecosystem services value in China (Table 5). The table is widely used by Chinese scholars (Liu et al., 2009; Xu et al., 2016; Li et al., 2010; Peng et al., 2016; Wang and Sun, 2016; Xu et al., 2016). According to the study by Xie (Xie and Xiao and Lu, 2006), we chose 9 types of ecosystem services, including gas regulation, climate regulation, water conservation, soil formation and protection, waste treatment, biodiversity conservation, food production, supply of raw materials, and entertainment and culture.

Table 5. Equivalent value per unit area of terrestrial ecosystem services in China

\begin{tabular}{c|c|c|c|c|c|c}
\hline Ecosystem services & $\begin{array}{c}\text { Forest } \\
\text { land }\end{array}$ & Grassland & $\begin{array}{c}\text { Cultivated } \\
\text { land }\end{array}$ & Wetland & $\begin{array}{c}\text { Water } \\
\text { area }\end{array}$ & $\begin{array}{c}\text { Unused } \\
\text { land }\end{array}$ \\
\hline Gas regulation & 3.50 & 0.80 & 0.50 & 1.80 & 0.00 & 0.00 \\
Climate regulation & 2.70 & 0.90 & 0.89 & 17.10 & 0.46 & 0.00 \\
Water conservation & 3.20 & 0.80 & 0.60 & 15.50 & 20.38 & 0.03 \\
Soil formation and protection & 3.90 & 1.95 & 1.46 & 1.71 & 0.01 & 0.02 \\
Waste treatment & 1.31 & 1.31 & 1.64 & 18.18 & 18.18 & 0.01 \\
Biodiversity conservation & 3.26 & 1.09 & 0.71 & 2.50 & 2.49 & 0.34 \\
Food production & 0.10 & 0.30 & 1.00 & 0.30 & 0.10 & 0.01 \\
Supply of raw materials & 2.60 & 0.05 & 0.10 & 0.07 & 0.01 & 0.00 \\
Entertainment and culture & 1.28 & 0.04 & 0.01 & 5.55 & 4.34 & 0.01 \\
\hline
\end{tabular}

In this study, the land use types were divided into 6 categories, including forest land, cultivated land, water area, unused land, grassland, and construction land. Therefore, Table 5 was slightly modified to form a table of equivalent value per unit area of terrestrial ecosystem services in Nanping City (Table 6). Construction land was not included in Table 6 because ecosystem services provide a positive utility that meets the needs of human beings. However, construction land, such as rural residential land and industrial and mining land, constantly releases sewage, waste gas, and solid waste to the environment, which have a devastating effect on the natural ecological environment. Consequently, we did not account for the value of ecosystem services of construction land.

Table 6. Equivalent value per unit area of terrestrial ecosystem services in Nanping City

\begin{tabular}{c|c|c|c|c|c}
\hline Ecosystem services & Forest land & $\begin{array}{c}\text { Cultivated } \\
\text { land }\end{array}$ & Water area & Unused land & Grassland \\
\hline Gas regulation & 3.50 & 0.50 & 0.00 & 0.00 & 0.80 \\
Climate regulation & 2.70 & 0.89 & 0.46 & 0.00 & 0.90 \\
Water conservation & 3.20 & 0.60 & 20.38 & 0.03 & 0.80 \\
Soil formation and protection & 3.90 & 1.46 & 0.01 & 0.02 & 1.31 \\
Waste treatment & 1.31 & 1.64 & 18.18 & 0.01 & 1.95 \\
Biodiversity conservation & 3.26 & 0.71 & 2.49 & 0.34 & 1.09 \\
Food production & 0.10 & 1.00 & 0.10 & 0.01 & 0.30 \\
Supply of raw materials & 2.60 & 0.10 & 0.01 & 0.00 & 0.05 \\
Entertainment and culture & 1.28 & 0.01 & 4.34 & 0.01 & 0.04 \\
\hline
\end{tabular}


We can see from Table 6 that the equivalent value per unit area of ecosystem services of these land use types is based on the value per unit area of food production of cultivated land in Nanping, which can be calculated by Equation 10:

$$
E_{a}=\frac{1}{7} \cdot T_{a} \cdot T_{b}
$$

where $E_{a}$ represents the value per unit area of food production of cultivated land $\left(\mathrm{CNY} / \mathrm{hm}^{2}\right) ; T_{a}$ refers to the average grain yield per unit area $\left(\mathrm{kg} / \mathrm{hm}^{2}\right)$ in the study area; and $T_{b}$ is the average grain price in China $(\mathrm{CNY} / \mathrm{kg})$. By consulting the Nanping Statistical Yearbook, we found that the average grain yield per capita in Nanping City in 2015 was $5,700 \mathrm{~kg} / \mathrm{hm}^{2}$, and that China's average grain price in 2015 was $5.24 \mathrm{CNY} / \mathrm{kg}$. Hence, we obtained the value per unit area of food production of cultivated land in Nanping, which was $4266.85 \mathrm{CNY} / \mathrm{hm}^{2}$, by means of Equation 10.

The values per unit area of ecosystem services for land use types, except for cultivated land, were obtained using Equation 11 and Table 6.

$$
C V_{i j}=E_{a} \cdot f_{i j}
$$

where $i$ is a specific land use type. $j$ represents a specific ecosystem service. $C V_{i j}$ represents the value per unit area of specific ecosystem services of a specific land use type $\left(\mathrm{CNY} /\left(\mathrm{hm}^{2} \cdot\right.\right.$ year $\left.)\right) . E_{a}$ represents the value per unit area of food production of cultivated land $\left(\mathrm{CNY} / \mathrm{hm}^{2}\right) . f_{i j}$ refers to the equivalent value per unit area of specific ecosystem services of specific land use types.

Table 7. The value per unit area of ecosystem services of land use types in Nanping City (ten thousand $\mathrm{CNY} / \mathrm{hm}^{2}$ )

\begin{tabular}{c|c|c|c|c|c}
\hline Ecosystem services & Forest land & Cultivated land & Water area & Unused land & Grassland \\
\hline Gas regulation & 1.4933 & 0.2133 & 0.0000 & 0.0000 & 0.3413 \\
Climate regulation & 1.1520 & 0.3797 & 0.1962 & 0.0000 & 0.3840 \\
Water conservation & 1.3670 & 0.2560 & 8.6953 & 0.0128 & 0.3413 \\
Soil formation and protection & 1.6640 & 0.6229 & 0.0042 & 0.0085 & 0.5589 \\
Waste treatment & 0.5589 & 0.7012 & 7.7567 & 0.0042 & 0.8320 \\
Biodiversity conservation & 1.3909 & 0.3029 & 1.0624 & 0.1450 & 0.4651 \\
Food production & 0.0427 & 0.4267 & 0.0427 & 0.0042 & 0.1280 \\
Supply of raw materials & 1.1093 & 0.0427 & 0.0042 & 0.0000 & 0.0213 \\
Entertainment and culture & 0.5461 & 0.0042 & 1.8517 & 0.0042 & 0.0171 \\
Total & 9.3243 & 2.9497 & 19.6136 & 0.1791 & 3.0891 \\
\hline
\end{tabular}

\section{Prediction of ecosystem services value}

The predicted value of ecosystem services of all land use types can be calculated by Equation 12:

$$
E S V=\sum_{i=1}^{n} \sum_{j}^{m} A_{i} \times C V_{i j}
$$


where $E S V$ is the predicted value of ecosystem services, $A_{i}$ is the predicted area of a specific land use, and $C V_{i j}$ represents the value per unit area of ecosystem services of specific land use types. $n$ and $m$ refer to the number of land use types and ecosystem services, respectively.

\section{Results}

\section{Prediction accuracy of land use change}

The area of land use types in Nanping City in 2015 was predicted using the CAMarkov model and the area of land use types in Nanping City in 2005 and 2010. According to Equations 8 and 9, quantitative and spatial errors were present (Table 8). We found from Table 8 and Figure 5 that the quantitative and spatial prediction accuracy were greater than $90 \%$ and $89.85 \%$, respectively. Therefore, it is feasible to predict future changes in land use with the CA-Markov model.

Table 8. Accuracy of prediction of land use in 2015

\begin{tabular}{c|c|c|c|c|c|c}
\hline $\mathbf{2 0 1 5}$ & $\begin{array}{c}\text { Construction } \\
\text { land }\end{array}$ & $\begin{array}{c}\text { Forest } \\
\text { land }\end{array}$ & Water area & $\begin{array}{c}\text { Cultivated } \\
\text { land }\end{array}$ & $\begin{array}{c}\text { Unused } \\
\text { land }\end{array}$ & Grassland \\
\hline Actual value $\left(\mathrm{km}^{2}\right)$ & 1101.63 & 21380.69 & 624.84 & 1106.44 & 410.36 & 1644.75 \\
Validated value $\left(\mathrm{km}^{2}\right)$ & 1154.26 & 21057.99 & 645.50 & 1212.29 & 429.36 & 1775.21 \\
Quantitative error $(\%)$ & 4.78 & -1.51 & 3.30 & 9.56 & 4.63 & 7.93 \\
Spatial error $(\%)$ & 13.09 & 4.28 & 12.32 & 12.76 & 7.41 & 11.05 \\
\hline
\end{tabular}

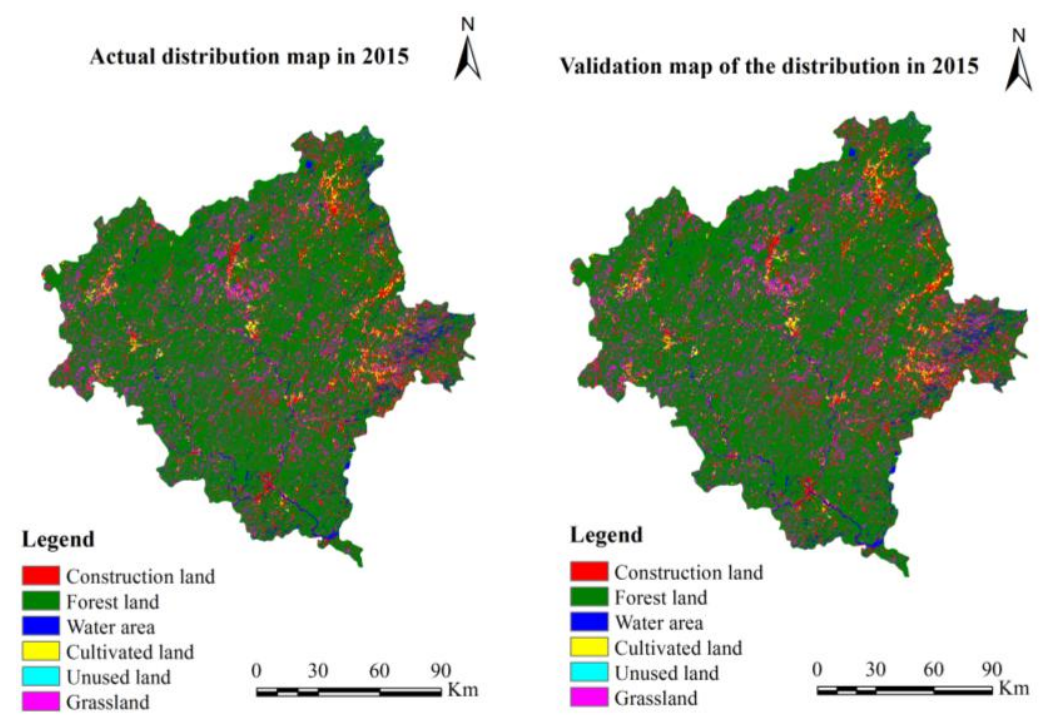

Figure 5. Comparison of the actual distribution and validated distribution of land use in 2015

\section{Prediction of land use change}

After completing the accuracy test, we predicted the change in land use types in 2020, 2025, and 2030 in Nanping by changing the number of simulated cycles in IDRISI to 5,10, and 15, respectively. However, the change in land use was insignificant from 2015-2025, so we only demonstrated the results of land use change in 2030. As 
shown in Table 9 and Figure 6, there were observable characteristics in the future changes in land use in Nanping.

Table 9. Comparison of the change in area of land use in 2015 and 2030

\begin{tabular}{c|c|c|c|c|c}
\hline \multirow{2}{*}{ Land use types } & \multicolumn{2}{|c|}{$\mathbf{2 0 1 5}$} & \multicolumn{2}{c|}{$\mathbf{2 0 3 0}$} & $\mathbf{2 0 1 5 - 2 0 3 0}$ \\
\cline { 2 - 6 } & Area $\left.\mathbf{( k m}^{\mathbf{2}}\right)$ & Proportion (\%) & Area $\left.\mathbf{( k m}^{\mathbf{2}}\right)$ & Proportion $\mathbf{( \% )}$ & Area change $\mathbf{( k m}^{\mathbf{2}} \mathbf{~}$ \\
\hline Forest land & 21380.69 & 81.39 & 21780.14 & 82.89 & 399.45 \\
Grassland & 1644.75 & 6.26 & 1430.55 & 5.44 & -214.20 \\
Cultivated land & 1106.44 & 4.21 & 1189.61 & 4.53 & 83.17 \\
Construction land & 1101.63 & 4.19 & 846.36 & 3.22 & -255.27 \\
Water area & 624.84 & 2.38 & 592.86 & 2.26 & -31.98 \\
Unused land & 410.36 & 1.56 & 435.10 & 1.66 & 24.74 \\
Total & 26268.71 & 100.00 & 26274.62 & 100.00 & 5.91 \\
\hline
\end{tabular}

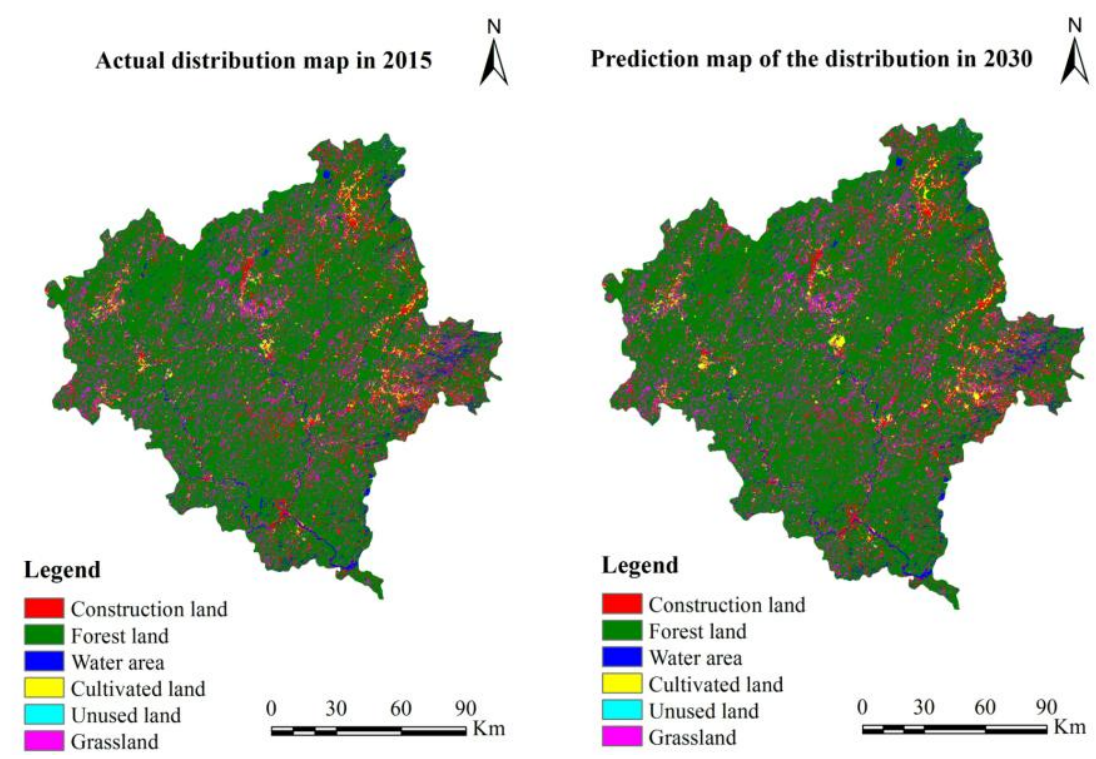

Figure 6. Comparison of the distribution of land use in 2015 and 2030

In the 2030 prediction, the total area of forest land reached $21780.14 \mathrm{~km}^{2}$ and the proportion of forest land to the study area increased from $81.39 \%$ in 2015 to $82.89 \%$ in 2030 , which is an increase of $1.50 \%$. This shows that over the 15 years, the ecological environment continues to be strengthened and the forest cover rate is sustained.

Compared to the area of grassland in 2015, the area in 2030 showed a significant reduction with a decrease of $214.20 \mathrm{~km}^{2}$. The decrease was closely linked with the development of the regional economy and the constant adjustment of the industrial structure. Consequently, more attention should be given to pasture degradation caused by overgrazing and natural disasters (Wang, 2013).

The area of cultivated land was predicted to increase by $83.17 \mathrm{~km}^{2}$ during the 15 years, indicating that the government's policy of protecting basic farmland and stabilizing the food supply will continue to play a role in this stage. 
Water area would decrease slightly in 2030 compared to 2015. Due to the continuous increase in population, the change in life style, and the increase in water utilization for agriculture and industry, the water area could continue to decrease, which should be given adequate attention.

By 2030, the area of construction land would be reduced from $1101.63 \mathrm{~km}^{2}$ in 2015 to $846.36 \mathrm{~km}^{2}$ in 2030 , which is a decrease of $255.27 \mathrm{~km}^{2}$. This means that the intensive development of land would increase in the process of urban construction and economic development in Nanping during those 15 years.

The change in area of unused land during the 15 years would not be significant. This is due to the fact that most of the unused land is situated in regions with harsh natural conditions and steep slopes, which is not easily accessible to humans.

\section{Prediction of ecosystem services value}

The services value and rate of contribution of ecosystems in 2015 and 2030 were calculated using Tables 7 and 9 and Equation 12.

It can be seen from Table 10 that the service value of the ecosystems from 20152030 would continue to increase slightly. By 2030, the total value of the services in Nanping would reach 227.72 billion CNY, which is an increase of 2.69 billion CNY. From the services value of different ecosystems, the value of forest land showed a slow growth but it remained at a relatively high value during the 15 years. The contribution rate of forest land in 2030 was $0.58 \%$ higher than that in 2015 . The services value and contribution rate of cultivated land and unused land also increased slightly. However, during the 15 years, the services value of water area and grassland continued to decrease, with a total decrease of 0.63 billion CNY and 0.66 billion CNY, respectively. The contribution rate of ecosystem value of water area and grassland was predicted to decrease by $0.35 \%$ and $0.33 \%$, respectively. Consequently, more attention should be given to the reduction in the services value of water area and grassland during these 15 years.

Table 10. The services value and contribution rate of different ecosystems in 2015 and 2030

\begin{tabular}{c|c|c|c|c|c|c}
\hline \multirow{2}{*}{ Ecosystem types } & \multicolumn{2}{|c|}{$\begin{array}{c}\text { Ecosystem services value (billion } \\
\text { CNY) and contribution rate (\%) }\end{array}$} & $\begin{array}{c}\text { Changing services } \\
\text { value (billion CNY) }\end{array}$ & $\begin{array}{c}\text { Changing } \\
\text { contribution rate (\%) }\end{array}$ \\
\cline { 2 - 6 } & \multicolumn{2}{|c|}{$\mathbf{2 0 1 5}$} & \multicolumn{2}{|c|}{$\mathbf{2 0 3 0}$} & $\mathbf{2 0 1 5 - 2 0 3 0}$ & $\mathbf{2 0 1 5 - 2 0 3 0}$ \\
\hline Forest land & 199.36 & 90.61 & 203.08 & 91.18 & 3.72 & 0.58 \\
Cultivated land & 3.26 & 1.48 & 3.51 & 1.58 & 0.25 & 0.09 \\
Water area & 12.26 & 5.57 & 11.63 & 5.22 & -0.63 & -0.35 \\
\hline Unused land & 0.07 & 0.03 & 0.08 & 0.04 & 0.01 & 0.01 \\
Grassland & 5.08 & 2.31 & 4.42 & 1.98 & -0.66 & -0.33 \\
Total & 220.03 & 100.00 & 222.72 & 100.00 & 2.69 & 0.00 \\
\hline
\end{tabular}

As shown in Table 11, excluding the service of waste treatment, the value of the remaining service types showed a slight increase over the 15 years. Most notably, the service values of soil formation and protection, gas regulation, and supply of raw materials in 2030 were over 0.40 billon CNY higher than those in 2015 . The order of various service values in 2030 were as follows: soil formation and protection > water conservation $>$ gas regulation $>$ biodiversity conservation $>$ climate regulation $>$ raw 
materials $>$ waste treatment $>$ entertainment and culture $>$ food production. In short, the total value of ecosystem services in Nanping was predicted to steadily increase over the 15 years.

Table 11. The value of ecosystem services in Nanping City in 2015 and 2030 (billion CNY)

\begin{tabular}{c|c|c|c}
\hline Ecosystem services & $\mathbf{2 0 1 5}$ & $\mathbf{2 0 3 0}$ & Changing value over 15 years \\
\hline Gas regulation & 32.72 & 33.26 & 0.54 \\
Climate regulation & 25.80 & 26.20 & 0.40 \\
Water conservation & 35.51 & 35.72 & 0.21 \\
Soil formation and protection & 37.19 & 37.78 & 0.59 \\
Waste treatment & 18.94 & 18.79 & -0.15 \\
Biodiversity conservation & 31.56 & 32.01 & 0.45 \\
Food production & 1.41 & 1.64 & 0.23 \\
Supply of raw materials & 23.80 & 24.24 & 0.44 \\
Entertainment and culture & 12.86 & 13.02 & 0.16 \\
Total & 219.82 & 222.71 & 2.89 \\
\hline
\end{tabular}

\section{Discussion and suggestions}

Land is a precious natural resource that is necessary for the survival of human beings and for urban development. Sustainable land use and rational planning of land are basic requirements for the development of the city, and are also the issues of most concern for land use decision-making departments (Bateman et al., 2013). Therefore, we provide the following countermeasures and suggestions according to the study results, which are aimed at providing useful information for land administration departments.

\section{(1) Cultivated land}

From the above prediction results, it was found that the area of cultivated land would decrease slightly from 2015 to 2030. However, the population in Nanping City will continue to increase during these 15 years. It would be particularly important to guarantee the basic supply of grain. Therefore, the protection of basic farmland as a basic land use strategy is of great significance for maintaining regional grain production and regional ecological security. The specific countermeasures and suggestions are as follows:

a) High-quality areas of cultivated land are defined as a basic farmland protection area, ensuring that the area and the quality of basic farmland do not decrease.

b) It is forbidden for other land uses to occupy basic farmland areas.

c) For ordinary cultivated land, construction projects should use as little cultivated land area as possible. If it is necessary to occupy cultivated land, only farmland with poor quality should be occupied.

d) Due to the abandonment of rural areas in Nanping City, it is forbidden to abandon cultivated land. Check the farmland that has been abandoned, and take corresponding measures to resume farming.

e) Developing unused land with a moderate slope as a reserve resource for cultivated land. It is forbidden to develop areas with slopes greater than $25^{\circ}$. 
f) Developing a responsibility system for farmland protection; designating the relevant leaders of the government as the first responsible person, and ensuring that the tasks of farmland protection are completed.

\section{(2) Grassland}

This study found that the grassland area would be significantly reduced by 2030 . Therefore, appropriate measures should be taken to protect the grassland area.

a) Implementation grassland development plans to increase grassland utilization so as to ensure adequate forage supply for livestock raised by farmers.

b) Planting grass according to scientific methods and actively introduce suitable pasture varieties.

c) Protecting the grassland and forbidding the burning of grassland. When weeds are eliminated and pests and diseases are removed, scientific measures must be taken to prevent damage to the grasslands.

d) It is forbidden to overgraze so as to prevent degradation of grassland. For degraded grasslands, measures should be taken to increase grass production and livestock husbandry.

e) Destruction of grassland should be investigated.

For forest land, construction land, and unused land, the prediction results performed well, but it is still necessary to make recommendations to ensure that this favorable situation is maintained. The specific recommendations are as follows:

\section{(3) Forest land}

It is forbidden to develop and use natural forests. Practice the closing of mountains and forests, and encourage tree planting on barren slopes.

\section{(4) Construction land}

a) Construction land should be used intensively. Develop and utilize ground and underground space to support the construction of multi-level industrial plants in order to improve the utility rate of space.

b) Encouraging farmers to build houses in a centralized manner and prohibiting scattered distribution of rural buildings.

\section{(5) Unused land}

On the premise of protecting the ecological environment, developing the gentle slope zone will provide backup support for other land resources.

\section{Conclusions}

Based on CA-Markov model and equivalent value per unit area of terrestrial ecosystem services in China, we predicted the area of the land use types and ecosystem services value in 2030. The following main conclusions are as follows.

From 2015 to 2030, the area of the forest land and cultivated land increase obviously. The area of the grassland and construction land show a significant decrease, while the water area and unused land area do not change significantly. Compared with 2015, the change of the spatial distribution pattern of land use types in 2030 is not significant. 
It has been found that the total value of ecosystem services will continue to rise from 2015 to 2030. It has been estimated that the ecosystem services value in Nanping City will reach 222.72 billion CNY in 2030. The increasing speed of the service value of forest land will slow down, but the contribution rate of forest land in 2030 is still $0.58 \%$ higher than 2015. The improvement of the ecosystem services value in the study area is mainly due to the increasing value of service types such as gas regulation, soil formation and protection, biodiversity conservation and supply of raw materials. More significantly, the services value of the gas regulation and soil formation and protection increase by over 0.50 billion $\mathrm{CNY}$ during the 15 years.

Acknowledgements. The authors are so grateful to National Science and Technology Major Project of the Ministry of Science and Technology of China (Fund No. 2017YFD0601304) for financial support.

\section{REFERENCES}

[1] Bateman, I. J., Harwood, A. R., Mace, G. M., Watson, R. T., Abson, D. J., Andrews, B., Binner, A., Crowe, A., Day, B. H., Dugdale, S. (2013): Bringing ecosystem services into economic decision-making: land use in the United Kingdom. - Science 341: 45-50.

[2] Cetin, M. (2015): Evaluation of the sustainable tourism potential of a protected area for landscape planning: a case study of the ancient city of Pompeipolis in Kastamonu. International Journal of Sustainable Development \& World Ecology 22: 490-495.

[3] Cetin, M. (2016): Sustainability of urban coastal area management: A case study on Cide. - Journal of Sustainable Forestry 35: 527-541.

[4] Cetin, M., Adiguzel, F., Kaya, O., Sahap, A. (2018): Mapping of bioclimatic comfort for potential planning using GIS in Aydin. - Environment Development \& Sustainability A Multidisciplinary Approach to the Theory \& Practice of Sustainable Development 20: 115.

[5] Costanza, R. (1997): The value of ecosystem service and nature capital in the world. Nature 387: 235-260.

[6] DeFries, R. S., Foley, J. A., Asner, G. P. (2004): Land-use choices: balancing human needs and ecosystem function. - Frontiers in Ecology and the Environment 2: 249-257.

[7] Fu, B., Wang, S., Su, C., Forsius, M. (2013): Linking ecosystem processes and ecosystem services. - Current Opinion in Environmental Sustainability 5: 4-10.

[8] Fu, B., Zhang, L., Xu, Z., Zhao, Y., Wei, Y., Skinner, D. (2015): Ecosystem services in changing land use. - Journal of Soils \& Sediments 15: 833-843.

[9] Gaglio, M., Aschonitis, V. G., Gissi, E., Castaldelli, G., Fano, E. A. (2017): Land use change effects on ecosystem services of river deltas and coastal wetlands: case study in Volano-Mesola-Goro in Po river delta (Italy). - Wetlands Ecology \& Management 25: 67-86.

[10] Inkoom, J. N., Frank, S., Fürst, C. (2017): Challenges and opportunities of ecosystem service integration into land use planning in West Africa - an implementation framework. - International Journal of Biodiversity Science Ecosystem Services \& Management 13: 67-81.

[11] Kim, S. J., Lee, Y. J. (2007): The effect of spatial scale and resolution in the prediction of future land use using CA-Markov technique. - National Bureau of Economic Research 10: 225-234.

[12] Koellner, T., Baan, L. D., Beck, T., Brandão, M., Civit, B., Margni, M., Canals, L. M. I., Saad, R., Souza, D. M. D., Müller-Wenk, R. (2013): UNEP-SETAC guideline on global land use impact assessment on biodiversity and ecosystem services in LCA. International Journal of Life Cycle Assessment 18: 1188-1202. 
[13] Lawler, J. J., Lewis, D. J., Nelson, E., Plantinga, A. J., Polasky, S., Withey, J. C., Helmers, D. P., Martinuzzi, S., Pennington, D., Radeloff, V. C. (2014): Projected landuse change impacts on ecosystem services in the United States. - Proceedings of the National Academy of Sciences of the United States of America 111: 7492-7497.

[14] Liu, M., Hu, Y., Chang, Y., He, X., Zhang, W. (2009): Land use and land cover change analysis and prediction in the upper reaches of the Minjiang River, China. Environmental Management 43: 899-907.

[15] Li, Z., Liu, W. Z., Zheng, F. L. (2010): Land use change in Heihe catchment on loess tableland based on CA-Markov model. - Transactions of the Chinese Society of Agricultural Engineering 26: 346-352.

[16] Peng, W. F., Zhou, J. M., Fan, S. Y., Yang, C. J. (2016): Effects of the land use change on ecosystem service value in Chengdu, Western China from 1978 to 2010. - Journal of the Indian Society of Remote Sensing 44: 197-206.

[17] Ramezani, N., Jafari, R. (2014): Land use/cover change detection in 2025 with CAMarkov chain model (case study: Esfarayen). - Journal of Physical Chemistry 63: 788793.

[18] Song, W., Deng, X. Z., Yuan, Y. W., Wang, Z., Li, Z. H. (2015): Impacts of land-use change on valued ecosystem service in rapidly urbanized North China Plain. - Ecological Modelling 318:245-253.

[19] Simmons, J. A., Currie, W. S., Eshleman, K. N., Kuers, K., Monteleone, S., Negley, T. L., Pohlad, B. R., Thomas, C. L. (2008): Forest to reclaimed mine land use change leads to altered ecosystem structure and function. - Ecological Applications A Publication of the Ecological Society of America 18: 104-118.

[20] Subedi, P., Subedi, K., Thapa, B. (2013): Application of a hybrid cellular automatonMarkov (CA-Markov) model in land-use change prediction: a case study of Saddle Creek Drainage Basin, Florida. - Science and Education 1: 126-132.

[21] Tolessa, T., Senbeta, F., Abebe, T. (2016): Land use/land cover analysis and ecosystem services valuation in the central highlands of Ethiopia. - International Tree Crops Journal 26: $111-123$.

[22] Veldkamp, A., Verburg, P. H. (2004): Modelling land use change and environmental impact. - Journal of Environmental Management 72: 1-3.

[23] Verburg, P. H., Schot, P. P., Dijst, M. J., Veldkamp, A. (2004): Land use change modelling: current practice and research priorities. - Geojournal 61: 309-324.

[24] Wang, J. (2013): Development model of agrorecycling economy - a case study of Nanping city, Fujian, China. - Institute of Agro-ecology Fujian Agriculture and Forestry University, Fuzhou.

[25] Wang, M., Sun, X. (2016): Potential impact of land use change on ecosystem services in China. - Environmental Monitoring \& Assessment 188: 248.

[26] Xie, G., Xiao, Y., Lu, C. (2006): Study on ecosystem services: progress, limitation and basic paradigm. - Journal of Plant Ecology 30: 191-199.

[27] Xie, G., Wenhua, L. I., Yu, X., Zhang, B., Chunxia, L. U., Kai, A. N., Wang, J., Kang, X. U., Wang, J. (2010): Forest ecosystem services and their values in Beijing. - Chinese Geographical Science 20: 51-58.

[28] Xu, S., Silveira, M. L., Inglett, K. S., Sollenberger, L. E., Gerber, S. (2016): Effect of land-use conversion on ecosystem $\mathrm{C}$ stock and distribution in subtropical grazing lands. Plant \& Soil 399: 233-245.

[29] Xu, Y., Tang, H., Wang, B., Chen, J. (2016): Effects of land-use intensity on ecosystem services and human well-being: a case study in Huailai County, China. - Environmental Earth Sciences 75: 416.

[30] Yang, G., Liu, Y., Wu, Z. (2007): Analysis and simulation of land-use temporal and spatial pattern based on CA-Markov model. - Geomatics \& Information Science of Wuhan University 32: 414-418 (in Chinese). 
[31] Zhao, G., Chen, Y., Chen, J., Li, J. (2011): Spatial scale sensitivity of CA-Markov model. - Scientia Geographica Sinica 31: 897-902 (in Chinese).

[32] Zhang, Y. X., Feng, G. J. (2017): Study on dynamic land use planning. - China Land Sciences 31: 25-32 (in Chinese). 